\title{
The Religious Carol in Transylvania -Function and Symbol
}

\author{
Dan Alexandru Streza*
}

In the context of Romanian folkloric tradition, the carol represents one of the oldest cultural elements. The first part of this article defines the genre and functions of the Romanian carol, and explains that its basic function is the conveyance of wishes, referring to all aspects of the social and personal life of the recipient. As far as the nature of the carol is concerned, the second part of the article reveals some characteristics of the sense and symbol of the religious carol, concluding that carols are part of those traditional texts and melodies that can be called Eucharistic chants. Their preservation and practice in different areas of the country highlight their worth, as they essentially represent liturgical echoes arising from the ethnogenesis of the Romanian nation.

Keywords: Carol, Christmas, Religious Folklore, Orthodox Sacred Music.

\section{The carol ${ }^{1}$ : musical genre and function in Transylvania}

An important chapter in Romanian traditional culture is represented by the folklore surrounding the main holidays of the year, wherein the intertwining of the beliefs and practices of the Romanian people with religious elements pertaining to Christian and pre-Christian times is oftentimes combined in rituals that look like true performances. One of these is the custom of going carolling.

The complexity of this rite is obvious, as it is a ceremonial act of communication and interrelation. The folkloric creations that underlie carolling impress by the different blends of varying proportions of poetical, musical, choreographic and dramatic elements.

These all combine into a unified collection of signs, clues and symbols and, just as in any other communication process, they acquire an abundance

\footnotetext{
*Dan Alexandru Streza, Deac. PhD, Teaching Assistant at the "Andrei Şaguna" Faculty of Orthodox Theology, "Lucian Blaga” University of Sibiu, Romania. Address: Mitropoliei 20, 550179, Sibiu, Romania; e-mail: dan_steza@yahoo.com.

1 The Carol is according to The Oxford dictionary: "A religious folk song or popular hymn, particularly one associated with Christmas", http://www.oxforddictionaries.com/definition/ english/carol, viewed on $24^{\text {th }}$ March 2016. In Romanian tradition this meaning extends to "a popular augural song practiced around Christmas time". It is also true that the corpus of Romanian carols (summing around 5000 carols in many variations) contains just a small number of religious carols (around 300 songs), which actually deal with the Themes of the Nativity of Christ. For more details see: Ileana Szenik, Ioan Bocșa (eds.), Colinda în Transilvania - Catalog Tipologic muzical, Vol. I, Cluj-Napoca 2011, p. 15-24.
}

RES 8 (1/2016), p. 76-84

DOI: $10.1515 /$ ress-2016-0005 
of meanings, which, nevertheless, are often hard to determine, due to their semantic variety. ${ }^{2}$

In the context of Romanian folkloric tradition, the carol represents one of the oldest cultural elements. This is evident both in the remarkably exquisite and varied poetical language of the carols, and particularly in its musical language, which is highly complex and suggestive. ${ }^{3}$ This viewpoint emphasizes the documentary value of the carol, whose archaic character expresses the longevity and continuity of the Romanian population in the Carpathian-Danube-Pontic region.

Judging strictly from a literary, musical and choreographic point of view, of all artistic productions that are specific to customs celebrated all year round, except for the poem Pluguşorul, carols hold the greatest significance. The carols offer, time and again, the image of certain ancestral historical, social, or ritual realities that epitomize true monuments of art from a distant and practically unknown era.

The message of carols is always future oriented, and their practical function is that of being augural. Everything they sing about must come to fruition, to the happiness and well-being of all recipients. This projection into the future stands at the foundation of the quality of optimism, of total trust in man and his strengths that the carols transmit. In the entirety of Romanian folklore, the carols are the only instruments which assert the hope that good wishes come true in such a positive manner.

It is worth noting that the augural function receives an important ceremonial character in carols, and that ritualistic wishes for prosperity and fertility mark the transition periods at the beginning of the calendar year. This function, however, cannot be dissociated from the topic area, which classifies carols according to the type and age of their recipients (carols dedicated to a young woman or man who is about to wed, carols for the elderly), to their occupation (shepherd, mayor, notary, judge, priest, etc.), their social status (carols for wives, widows, newly-married). There are also a number of mourning carols, such as "Mă luai, luai" and "Mioriţa".

Thus, the basic function of the carol is to convey wishes that refer to all aspects of the social and personal life of the recipient, and that are expressed through general literary topics. Also, the theme variation and the highly diverse pool of topics tackled by the carols generate secondary functions that

\footnotetext{
2 Paul Miereanu, Colindul sibian: tematică poetică şi funcţionalitate, Sibiu, 2006, p. 7.

3 See: Alina Stan, Limbajul muzical al colindelor din Transilvania, Cluj-Napoca, 2009, passim.

4 Gheorghe Oprea, Folclorul muzical românesc, București, 2002, p. 398.
} 
are subordinate to the main function. Among these subsidiary functions, the most notable are:

- the communication function, which helps transmit a certain quantity of information from one subject to another;

- the initiative function, manifested also in the way the ritual plays, which is related to the existence of hierarchic roles and behavioural rules within the carollers' group;

- the function of consolidation regarding the cohesion of the social group and the spiritual communion between the carollers, or between the carollers' group and the hosts who receive them;

- the protective function, for the recipients and for their assets;

- the normative function, which provides thinking, emotional and behavioural patterns, or models of sanctioning moral lapses;

- the cathartic function, which acts on a psychological plane like a valve that allows built-up tensions to escape;

- the onomastic function, oftentimes present in the title of the carol as well; Colinda Sfântului Niculae (Saint Nicholas's Carol), Colinda lui Sânt Ionu (Saint John's Carol), a Sfântului Patru (Saint Peter's Carol), Colinda lui Sânicoară (again, Saint Nicholas's Carol);

- the function of manifesting and experiencing the sacred - the carols and carollers help extend the mystical reality of God's presence in the world through the Holy Eucharist, to the entire community. ${ }^{5}$

The carols present the world, natural phenomena and the elements in a unique ambiance. Generally, they dwell upon three facets of rural life: housekeeping, farming and assets with all that these entail, the strength and beauty of young men, and the heroism and love they possess, analysed from the perspective of a possible marriage. $^{6}$

The functional types of carols comprise:

- the window carols, which preserve the form of generalized wishes (i.e. waking up the hosts and announcing the event that is celebrated);

- the actual carols, containing personalized wishes related to various topics;

- the daybreak carols, usually found in Transylvania and a part of Oltenia (Wallachia Minor), with the particularity that the Transylvanian ones bear core similarities with the window carols.

Alongside these and according to the persons who perform the carols, there are children's carols - short and direct general wishes that announce the

5 Ileana Szenik, Ioan Bocşa, "Studiu introductive" in: Ioan Bocşa (coord.), Colinde Româneşti, Cluj-Napoca, 2003, p. 11-12.

6 P. Miereanu, Colindulsibian, p. 13-14. 
holiday and wish an abundance of crops and cattle upon the household, and boys groups' carols that are individualized and have various functions in keeping with the type of carol sung and the person who receives it. ${ }^{7}$

From a poetical standpoint, the carol's function of conveying wishes is, most of the time, made up of two separate parts:

- the main part that comprises the indirect wish, and

- the final statement or direct wish that is done on the basis of certain different models.

The wish, either direct or indirect, founded on its ancient meanings, has become more and more of a tradition, a simple custom, and this change of function has taken a toll on the content of the carols' lyrics. The disappearance of the ancient function has brought about a change of the genre's meaning and has allowed the intrusion of a series of new elements alongside the old ones. In this process, the old wishing rituals have changed their authentic meaning and morphed into poetical images, thus pushing the carols outside the ceremonial zone and into the artistic domain. ${ }^{8}$

\section{The religious carol: sense and symbol}

The intention of bringing the carols before the public eye and drawing attention to their musical value somehow overpasses the honest pursuits of the folkloric researchers, who also share the sincere desire to save and safeguard these values. Hence, besides collecting, archiving and classifying carols and folkloric traditions, the task of spiritual ethnology in particular, as well as that of religious folkloristic, is to rediscover through them the roots of ancestral spirituality, which are defining for the spiritual structure of the Romanian people.

Carols belong to those traditional texts and melodies that can be called Eucharistic chants; their preservation and practice in different areas of the country highlight their worth, as they represent essentially liturgical echoes arising from ethnogenesis. Religious carols are expressions and extensions of the Holy Liturgy within the community, because the Holy Eucharist represents the consummate gratitude and thorough praise for the new life God has prepared for men, not only personally or individually, but also from an ethnic-communal point of view, by allowing the Romanian people to form inside the Carpathian-Danube-Pontic fortress. ${ }^{9}$

The harsh conditions surrounding both the evangelization and the formation of the Romanian people on its ancestral land were alleviated by the

\footnotetext{
Ibidem, p. 32.

8 Ibidem, p. 33-34.

9 Ilie Moldovan, Ecouri liturgice din etnogeneza românilor, Sibiu, 2006, p. 10.
} 
great joy of the Lord's Nativity. It was upon this joy that the other gifts of Romanian Christianity flourished and were endowed with meaning. Consequently, when approaching this treasury of religiousness, it is impossible to disregard the foundation of spiritual life, the great Mystery of joy, i.e., the Holy Eucharist. Therefore, in the process of researching and defining the religious carol, one must pay attention to its ultimate meaning and purpose, that is, to the confession of the true faith, not so much as an intellectual act, but mostly as the joy of living in Christ. ${ }^{10}$

Unfortunately, ethnology studies today have strongly disavowed anything that resembles authentic religious value in the Romanian carol. There is an evident massive and systematic tendency among the specialists in ethnology and folkloristics to regard the carol and the carolling act as nothing more than an ancient song and custom, a testimony to some long-lasting cultural traditions that were born in ancient times. Far from considering the carol as the carrier of a divine message, it is only viewed as a thought and manifestation pattern of the densest and most diverse kind, as it represents original, ceremonial texts. ${ }^{11}$

However, Romanian carols fundamentally incorporate a divine factor, for the Mystery of the Holy Eucharist has left a significant mark on their text and style of singing. As Father Ilie Moldovan notes, the carol affords a glimpse into the remnants of a divine presence that was there when the Romanian people were shaped. Regrettably, though, divine intervention from the ethnogenesis is often seen as a mere illusion, and the carol, being its carrier, is considered downright sorcery. ${ }^{12}$

This strictly rational interpretation claims that the carol is defined by an underlining of magic, inherited from the oldest times, and this magic principle is at the basis of all carols. The custom of going carolling thus becomes a custom that is magic par excellence, as Petru Caraman, a well-respected and recognized name in the Romanian ethnological field, states. He defines the custom of going carolling as the means by which magic pre-Christian elements were preserved as practices and especially as language patterns. In other words, "it is the custom wherein the initiated and attentive eye can have glimpses of ancestral eras. And miracle working arch-primitive procedures pertaining to an ancient tradition come to light in it." 13

According to this perception, the carollers seem to be some sort of wizards possessing wonder-working powers, for they are thought to bring

$10 \quad$ Ibidem, p. 11.

11 Monica Brătulescu, Colinda românească, București, 1981, p. 13-63.

12 I. Moldovan, Ecouri liturgice, p. 12.

13 Caraman Petru, Descolindatul, Iaşi, 1997, p. 115-116. 
health and happiness to each house they visit, as magical carriers of luck, wealth and prosperity, of health and longevity. Carolling itself, "when seen in its entirety and in the context of the means it employs in its function, appears to be a complex of magical acts executed by carollers with the precise intention of causing happiness, material well-being and prosperity all around the households they visit". ${ }^{14}$

Unfortunately, the majority of ethnologists consider themselves not only advocates of this trend, but most of all followers of the unmatched expert in religious matters, Mircea Eliade, who states: The conversion to Christianity has given way to numerous re-interpretations and re-analyses of the ancestral traditions, yet it has not managed to wipe out the pagan heritage. ${ }^{15}$ One has to note, however, that although this pagan heritage somehow seeps into the present via the dark alleys of magic, it is incorrect to generalize this tendency and extend it to the entire people and the whole of its customs, for the process of conversion to Christianity, and subsequently of renunciation of paganism, is deeply embedded in the very being of the Romanian people, which was born Christian.

This Carpathian-Danube Christianity, generator of new values, has actually produced a radical change in the interpretation of the vision statement on life. For instance, a fundamental difference between Christian and pagan cultures lies in the understanding of time. To the antique pre-Christian mind, time is nothing but a "moving image of eternity", a cyclic and recurrent motion that denotes an astronomic time which does not open history towards eternity, but rather encapsulates it.

Conversely, the carol chorus "Lerui ler" that opens up the prospect of entering into the Kingdom of God, shows that history is a motion from the moment of creation to that of attained perfection, that flows from a unique, irreversible direction, constantly led or supervised by God's Providence. ${ }^{16}$

Then again, the faithful themselves are the ones waiting for God, and the significance of the words that denote the act of bringing God into the houses of Christians is recorded thus: Why then, who is He that comes with them?/ It is the Good God Himself. Father Ilie Moldovan identifies in these words not their metaphorical sense, but their actual, fully objective meaning that translates into the fact that the carollers are also faithful people, who took Holy Communion before they went carolling. Only in this manner, through

14 Ovidiu Bârlea, "Colindatul în Transilvania" in: Anuarul Muzeului Etnografic al Transilvaniei, Cluj-Napoca, 1969, p. 297-301.

15 Mircea Eliade, Ocultism, vrăjitorie şi mode culturale, București, 1997, p. 15.

16 I. Moldovan, Ecouri liturgice, p. 48. 
the dignity offered by the Mystery of Holy Baptism and actualised by Holy Communion, do the carollers become worthy of mingling with the hosts of heralds of the Lord's Nativity. Hence, they give a testimony about the act they perform, for they truly bring God to the ones they visit, not just in a hypothetical, subjective way, but in a very objective way. ${ }^{17}$

Therefore, a fuller and more complete view of the carol presupposes the extension of the perspective towards the theological sphere, which is centred on the most important Christian Mystery, the Holy Eucharist. From this point of view, the reference point is the chorus "Lerui Ler", whose liturgical genesis dates back to the ancient times when the Romanian people emerged. The biblical expression of praise "Aleluia" ("Hallelujab") has become a word of praise in the Romanian language by the rhotacization of the "l" consonant, "aleruia", "leruia" "lerui" "ler" - the word that impresses its nuance on the carol's most authentic meaning. This theophonic word - one that bears God, as Father Ilie Moldovan notes, is the joy-filled greeting of those who see God's arrival and become acquainted with His presence. "Here He is" could be the most appropriate way of translating this word, which is otherwise impossible to translate, especially after having acquired the Romanian sonorous configuration: "Lerui Ier". Perhaps the most significant thing that needs to be mentioned is that this word forms a connection between the salutation of the Angel at the Lord's Nativity and the greeting that is occasioned by His Resurrection: Gabriel the Archangel told the Holy Virgin "Rejoice!" when he announced the Birth of Christ, and it is with the same "Rejoice!" that he would later greet the myrrh-bearing women, when proclaiming the Resurrection. In this way, the Romanians were able to use this "Lerui ler", which means "Aleluia" (n. transl. En. Hallelujah), only in the context of an authentic Christian life. ${ }^{18}$

As far as the nature of the carol is concerned, it is safe to say that it essentially implies the Eucharistic mystery, because the carol is not only the carrier of a divine message, but also itself a divine gift. This is a true fact that ethnological studies have almost entirely overlooked. The meaning of the "Lerui ler" chorus suggests that the Nativity cannot be conceived without the celebration of the Holy Liturgy, wherein the faithful receive the gift of all gifts, the Holy Eucharist. Thus, a true definition of the carol must take into account the message it conveys: "we are raising it to the skies and offering it to the host!" This highlights three central purposes of the carol:

- $\quad$ to unveil the truth of a divine presence in the lives of the faithful;

17 Ibidem, p. 51

18 Ibidem, p. 14. 
- to revive the Christian principles that have been imprinted on the Romanian people's conscience since its ethnogenesis in the Carpathian-Danube region;

- to support the principle of constant regeneration of the Romanian people, while keeping and promoting the authentic Christian values of its ancestors. ${ }^{19}$

In order to be thus perceived, the carols must be regarded in their innermost living spirit, visible during the major feasts, and always in accord with their Eucharistic and divine meaning. That communitarian existence is going through a crisis at present is due to the fact that the holidays are either extinct or Babylonic in nature, and people are attempting to reduce the invaluable richness of religion and carols to the level of a horizontal, sense-only based existence, instead of trying to exert themselves and rise through spiritual efforts to a level that may allow them to sample these wonderful gifts from God.

Early Christianity represented more than a doctrine intended to influence life on Earth. It was meant to inaugurate a human community within this space, by extending Christ's Life into each and every faithful Christian, like a living yeast, invisible but real, with the goal of leavening the whole batch of human dough, and of becoming truly visible only at the Parousia. In this respect, it is easy to note that part of the carols are meant to announce, along with the joy of the Lord's Nativity, the daunting quality of the final Judgement Day. "Only Thou Lord dost know/ When the world shall end / The angels shall then proclaim!" Undoubtedly, the authentic carol conveys the message that the eschatological times are already here. Christ's Resurrection, which is celebrated even at Christmas, as well as the Pentecost, seems to be both the inaugural and the decisive event of the Judgement. For that reason, there is no doubt that the carol's main task is to uncover the Truth that theories on the return to pre-Christian myths are trying to distort and, obviously, to betray. ${ }^{20}$

\section{Conclusions}

In the Romanian folkloric tradition, the carol represents one of the oldest cultural elements. From a poetical standpoint, the carol's main function is that of conveying wishes. This implies two separate facets: one that comprises the indirect wish, and the final statement or direct wish which is accomplished through certain different models. The wish, either direct or indirect, founded on its ancient meanings, has become more and more of a tradition,

\footnotetext{
19 Ibidem, p. 26.
}

20 Ibidem, p. 49. 
a simple custom, and this change of function has taken a toll on the content of the carols' lyrics.

In another view, Romanian carols essentially incorporate a divine factor, centred on the essence of the Christian life, the Holy Eucharist. It is living faith that has left a considerable mark on their text and style of singing. Therefore, this view of the carol presupposes the extension of the perspective towards its theological and ethical meaning, expressed with such joy and hope in these wonderful folkloric creations. 